\title{
From goalscorer to politician - The case of Romário and Football Politics in Brazil
}

During his playing days, the Brazilian striker Romário was one of the most famous footballers in the world. He played for three of Brazil's top clubs in Rio de Janeiro, as well as Barcelona and PSV Eindhoven. He won the World Cup and scored over one-thousand goals throughout his career. After this successful career, Romário entered politics, first as a deputy in the city of Rio and later as a senator in the state of Rio de Janeiro. Romário's electoral success is not simply down to his footballing ability, nor the popularity of the sport in Brazil. Sports stardom, celebrity and celebrity politicians are also engaging with complex cultural processes. He has traded on his footballing stardom, but he also connects with his electorate through specific policy campaigns that resonate particularly well to with his Brazilian voters. More importantly, he uses football and his footballer career as a metaphor for the wider problems facing Brazilian society. Drawing on literature from Sports Stardom, Celebrity and Celebrity Politicians, this article charts the political career of Romário within the socio-political context of Brazil and argues that celebrity politicians still need to engage with their audiences regardless of their previous careers.

Keywords: Football; Brazil; Celebrity; Sport Stars; Celebrity Politicians.

\section{Introduction}

It is one of the iconic moments in world football. Shortly before Brazil's quarterfinal match against Holland in the 1994 World Cup in the USA, the wife of Bebeto gave birth to their third child. After scoring Brazil's first goal against the Dutch, the forward celebrated by holding his hands together and rocking an imaginary baby. His teammate Romário celebrated alongside him in the same way. Two Brazilian strikers demonstrated solidarity and a love of the family on the world stage. Sixteen years later, the two (now former) players were in the news again. This time they had both been elected as political representatives; Bebeto in the state legislature of Rio de Janeiro, and Romário into the Chamber of Deputies of the national parliament. In a country whose international image is dominated by football, it is not exceptional that two World Cup-winning players had been successful in political elections. Many Brazilians hold footballers, and especially World Cup winners, in high esteem and this gives these players an initial platform with which to enter politics.

Romário is one of the greats of Brazilian football. He claims to have scored over a thousand goals and has been labelled as one of the best strikers ever by the likes of Maradona, Roberto Baggio, Michael Laudrup and Johan Cruyff. Romário won the FIFA World Cup in 1994, which followed a silver medal in the 1988 Olympics. He was also voted the world player of the year in 1994 and, after Pelé, he is the highest scorer in the national side's history. In addition, he has played throughout the world. Although the bulk of his career was played in Brazil, he also won the Dutch league three times with PSV Eindhoven, the Spanish League with Barcelona, alongside spells at Valencia, Miami and Adelaide. Most of Romário's games were played in Rio de Janeiro, where he had spells 
with three of Rio's four clubs. He began his career at Vasco de Gama, before playing for Flamengo, and then their archrivals Fluminense. Further spells at Vasco followed, and it was at their home stadium, the São Januário, that Romário scored his one thousandth goal with a penalty kick. Although he has included goals from his youth career, this landmark is still widely recognised as a significant achievement. Thus, Romário combined the star name, international achievement, national icon and star player of Rio de Janeiro. When standing for election for the Brazilian Socialist Party as a national deputy for the state of Rio de Janeiro and later as a senator, Romário had a distinct advantage. He thus represents a 'celebrity politician' (Street, 2004, 2012; Marsh et al, 2010) or a 'famed non politico' (West and Orman, 2002); Romário has traded on his football stardom in order to place himself in the political spotlight.

It would be facile to suggest that his football stardom is the only reason Romário was elected. It denies the various socio-cultural aspects of Brazilian society and its political momentum. As Archetti (2001) argues in relation to Diego Maradona, understanding cultural context is vital when analysing national sporting heroes. The wider social and political context in Brazil also facilitates this transition, when a famous self-made man that represented the country abroad, coming from unprivileged areas, attracts personal identifications of voters.

Brazilian footballers are world-renowned and many ply their trade outside of the country, partly due to the financial problems of the clubs. Consequently, players have become potent symbols of Brazil. Street (2012) has highlighted that research into celebrity politics has focussed on the UK and US. Indeed much of this analysis has been on musicians and movie stars, as these reflect the popular culture of both nations. The same is true of academic attention on sport stars. The overwhelming focus in Andrews and Jackson (2001), Gilchrist (2005), and Smart (2005) has been on North American and British sports stars, and very little is mentioned of political involvement. Corrigan (2001), in the former edited volume, discusses Imran Khan and his post-cricket writings and their contribution to his participation in politics. Gilchrist (2005) is a rare example of an academic addressing political engagement by sport stars, but highlighted how they were often apolitical in order to avoid confrontation with their corporate sponsors.

This article seeks to expand this literature, contributing to the understanding of sports celebrities under socio-political contexts of a country like Brazil. In doing so, it will address the structural factors affecting Brazilian politics and football and how these factors potentially politicised football players into electable politicians, as Romário. This article draws on Brazilian football studies and political sciences, as well as international literature on sports stardom, celebrity and celebrity politicians. This forms the core theoretical foundation to analyse Romário's political discourses through speeches, interviews and positions during his career as deputy (2011-2014) and the first months of his office duties as senator (2015-2023).

\section{Sports Stardom, Celebrity and Celebrity Politicians}


91 A dual process helps to create the sporting celebrity in late Modernity. On the one hand 92 the sporting hero has attained fame through his or her own talents, hard work and 93 achievements. On the other, they are presented as celebrities by an insatiable media and 94 corporate sponsors. The sporting celebrity hero combines both aspects of this process. The sporting celebrity is not a manufactured product sold by a manipulative culture industry onto an unsuspecting public; the sports star has achieved something and is worshipped by his or her fans accordingly. In this way, sporting celebrity helps illustrate the combined processes. It is not a reductionist dualism that separates 'celebrities' from 'heroes'. Boorstin (1971: 70) helped create this dualism by asserting that 'the hero was a big man [sic]; the celebrity is a big name'. For Boorstin (1971), the celebrity is known for their 'well-knowness' and is manufactured by the media through 'pseudo-events'. Following this dualism, Smart (2005) argues that sport stars have achieved something; they have become heroes through sporting achievement. Despite this, they still are packaged and sold as commodities by corporate sponsors and popular media. Stars like Romário are still manufactured in the same way as other celebrities and this helps to sustain their profile.

The sporting celebrity achieves a central role in the national public's imagination; they become sacred figures. As CLR James (1963) argued, they can become the national heroes of the former colonies. They help place a nation on the world map and become reified as a result. This helps to explain the individualistic aspect of celebrity. 'Sport and sporting heroes,' as Gilchrist (2005: 121) argues, 'are essential in terms of representing an image of the nation to the rest of the world and, internally, play a part in hyper socialisation of the young and the formation of a culturally specific subjectivity'. Footballers like Romário emerge as global stars that represent Brazil. Yet this focus on individual stars is not automatic. Rojek (2001) argues that the social ingredients of democratisation, secularisation, and commodification create the conditions that allow celebrities to emerge. With growing democracy, sporting national heroes contribute a sense of national unity across a widening electorate. They become secular 'saints' as organised religion wanes and are packaged as commodities which contribute to consumer culture. Although it is dangerous to assume a uniform secularisation across the globe, especially when Catholicism still retains a powerful moral and cultural influence in countries like Brazil, the quasi-religious aspect of celebrity is important. The rituals around football help create totemic figures who represent a club or nation (author 1, 2013).

It is important to note that celebrities, whether sporting or not, are both processes and products (Marshall, 1997; Andrews and Jackson, 2001, Turner, 2004). The media help package and present celebrities to the audience (Boorstin, 1962; Marshall, 1997; Rojek, 2001; Whannel, 2001; Andrews and Jackson, 2001; Smart, 2005; Turner, 2004; Gilchrist, 2005). Television is a prime driver in this process; 'The role of the media in promoting 131 stardom and celebrity status', as Giulianotti (1999: 118) argues, 'is critical and reciprocal 132 for the biggest medium of all'. Like other nations, Brazil has also seen the emergence of a 133 globalised commercial media network, Globo. This network specialises in various forms of 134 'neo-television' (Eco, 1990), that present 'pseudo-events' (Boorstin, 1963), football, and novelas (soap operas). The ritualistic football season helps create it own soap opera, with 
136 narratives, characters and dramatic storylines. Significantly, Globo adheres to Maguire's 137 (1999) 'media-sport complex' as it is the official media partner of the main elite football 138 championships in Brazil, both national and local. Regular exposure on television helps propel football stars like Romário into the public consciousness.

The culture industry has a range of roles that help package and market sport stars and other celebrities as brands. These range from agents, lawyers, PR representatives, and corporate managers. Private sponsorship also helps propel the sports star into the wider media spotlight. Corporate brands, such as Nike, have helped promote stars like Michael Jordan and Tiger Woods (Andrews and Jackson, 2000; Gilchrist, 2005). The Brazilian predilection for utilising nicknames helps create these sporting brands and football stars. At one they symbolise the popular jogo bonito image of Brazilian football. No other nation has a team packed with players sporting their nicknames. In parallel, names like Pelé, Garrincha, Zico, Sócrates, Romário, Ronaldo, and Ronaldinho help create a quasi-mythic status for star players. They become world-renowned by a single moniker. These names help elevate Edison Arantes do Nascimento (Pelé), Arthur Antunes Coimbra (Zico), or Romário de Souza Fariai from a mere footballer to a star. More importantly, the use of nicknames is also informal and a social leveller; nicknames are used by friends. By extension, the mythic star player is also a friend who holds the same status as the fan. This assists the star footballer in their transition to political life.

Despite the extensive media and corporate support for these stars, celebrity is 'a negotiated terrain of significance' (Marshall, 1997: 47). There is a complex interwoven relationship between media, sponsors, agents, and the celebrities themselves. Despite the early academic focus on manufacturing celebrity, often narratives do not follow designated paths when they hit the public. Whannel (2001) argues that events can build a 'vortextuality' of their own. Audiences are not homogenous and they interpret celebrities and the media in varying ways (Hall, 1980; Abercrombie and Longhurst, 1998). The celebrity is thus open to a variety of 'collective configurations' (Marshall, 1997: xii) of gender, ethnicity, nationality, and others. In relation to sport, heroes are often tied to notions of masculinity (Whannel, 2001). Those individuals who understand their audiences are the ones who can best navigate the tumultuous waters of stardom.

Wider political context is vital in understanding the rise of the celebrity politician (Marsh et al., 2010). Growing individualisation means these celebrities become intimates - they are the key sites of where cultural meanings are negotiated (Marshall 1997:72-3). This is tied to a growing individualisation of society where personal beliefs and emotions are asserted (Meštrović, 1997) whilst public participation in politics is falling (Sennett, 1976; Putnam, 2000). Bang (2004) argues against this thesis. He suggests that people are still engaged in politics, but in a more individualistic way. Embracing the neo-liberal virtues of individual hard work, they engage in politics for personal reasons. These 'everyday makers' are reflexive and get involved in public participation for personal reasons rather than through duty or ideology. The growing public awareness and interest in politics and the exercise of power has seen the emergence of what Keane (2009) calls 'monitory democracy'. Politicians have now become publically accountable for their decisions. Much of this is tied 
181 to new media forms, especially the Internet. There is now a multiplicity of voices that are

182

183

184

185

186

187

188

189

190

191

192

193

194

195

196

197

198

199

200

201

202

203

204

205

206

207

208

209

210

211

212

213

214

215

216

217

218

219

220

221

222

223

224

225 monitoring, campaigning and lobbying politicians. With this growing awareness, new political movements, such as Lega Nord, Pim Fortuyn's List and the Tea Party, are claiming to speak out for unrepresented citizens (Keane, 2002). In the UK and Europe, this awareness has led to disillusionment with the traditional party system and a sense of 'antipartyism' (Lipow and Seyd 1996; Axford and Huggins 1998). In Brazil, the dissatisfaction with the situation or the distrust on traditional parties and politicians have constantly led to the appearance of opposition or protest votes during the democratic period (Baquero, 2000). As will be shown later, Romário is not a protest vote. Growing political interest amongst the populace ensures that 'politicians need to engage on a continuing basis with citizens persuading them to participate. To do so, they use the media and celebrity' (Marsh et al, 2010: 328).

The role of the media is the one unifying element of academic discourse on celebrity. Not only do they circulate images and stories about the celebrity, they also help present the celebrity in a certain way. The proliferation of print, television and social media helps to personalise and dramatise the celebrity in the public sphere (Gamson, 1994; Meyer, 2002). Celebrity politicians must now use the tools of celebrity to reach their audience (Marsh et al, 2010).

Like the sporting celebrity, the politician is also deemed to have certain qualities. They are seen as imbued from the audience. For Weber (1948), the charismatic authority was seen to be 'a certain quality of an individual personality by virtue of which he is set apart from ordinary men and treated as endowed with supernatural, superhuman, or at least specifically exceptional qualities'. More importantly, the charismatic has to continue to prove themselves to their audience (Weber, 1968: 1112-3) As Turner (2003: 14) eloquently puts it: "When success deserts the charismatic leader, so does his [sic] authority". Similarly, Durkheim (1915: 210) highlights how individuals can acquire "the demon of oratorical inspiration" in these moments of congregation: Like Weber, Durkheim suggests that this force "comes to him from the very group which he addresses" (Durkheim, 1915: 210).

Presentation of self is vital for the celebrity politician in the media age. Street (2004) argues that celebrity politics is a performance; they have to perform the correct persona in order to appeal to their audience. The heavily mediated world of popular culture informs and influences the political sphere. As Street (1997: 5) states, 'we 'read' our politicians through their gestures and their faces, in the same way that we read performers on television'. Meštrović (1997) has argued that the politician must give the appearance that they are all things to all people. More significantly, the celebrity politician must appeal to their audience (Weber 1968, Rojek, 2001; Marshall, 1997).

Romário is not the first Brazilian footballer to enter politics. One of the stars of the Brazil 1982 World Cup team, Zico, was appointed Sports Secretary in 1990, but resigned a year later after Congress rejected his proposal to reform the game and stop corruption. A similar process occurred a few years later when one of the world's most famous players, 
226 Pelé, was nominated as Extraordinary Minister for Sport in 1995. Roberto Dinamite is 227 another footballer who successfully traded on their sporting cultural capital. Dinamite 228 played for the Seleção and spent most of his career at Vasco da Gama in the 1970s and 229 1980s. After retiring from football he was elected to the Rio State Assembly and later 230 became president of Vasco da Gama. For the 2014 election, there were twenty-three 231 former football players that were candidates for deputies and senate in different Brazilian 232 states. Of these only seven were elected - Romário and Bebeto being the most famous 233 among them (Folha de S. Paulo, 2014). These numbers reinforce that football stardom 234 itself does not explain political elections.

\section{From goalscorer to politician: Romário and Brazilian football politics}

Brazil is one of the largest countries in the world and is now emerging as one of the world's most developing economies. The former Portuguese colony is a federal nation state that grants significant autonomy to the federal states and the municipalities. These complex and competing political institutions have helped to create a fragmented political system and this requires a strong state to unite the disparate groups. Replicating similar patterns in the former colonial overlordsii, military dictatorship became one way of uniting the nation. From winning independence from Portugal in 1889, Brazil has endured various periods of dictatorship or quasi-dictatorship. While the military dictatorship endured from 1964 to 1985, the civilian Getúlio Vargas represented a significant era of quasi-dictatorship from 1930 to 1946 . These periods altogether mean that a third of the $20^{\text {th }}$ century was marked by authoritarian governments in Brazil.

The population is ethnically heterogeneous. Native indigenous people saw the arrival of a large Afro-Brazilian population descended from slaves, immigrants from Portugal, Italy, Germany, and other European nations migrated to the former colony. Consequently, Brazil is not an 'ethnic nation' founded on a shared ethnic history (Smith, 1988). Ultimately, it becomes the apposite example of an 'imagined community' (Anderson, 1983). As inhabitants of a nation do not know every other citizen, they still have a shared sense of identity. For Anderson (1983), these 'imagined communities' have a series of shared rituals that unites all inhabitants. Essentially, the nation is constructed in the cultural sphere through the shared rituals of language, media, and history. Yet there is still an international flavour to nationalism, as Leite Lopes (2007: 75) states, 'if imagined communities are built upon specific regional elements of local traditions, these collective movements are, on the other hand, greatly inspired by ideas that circulate internationally'. The World Cup, in particular, has been entwined with nationalism from its origins. The first men's World Cup in 1930 was held in Uruguay to coincide with the centenary of the nation's foundations. Since then football has become a source of international prestige (Negreiros, 2009) for the imagined community of Brazil.

In Brazil, football provides the potent symbol of national prestige and sporting heroes that reflect the nation's inhabitants. Helal (2003) describes the sporting heroes have similar histories of overcoming difficulties during their lives, but the Brazilian heroes have also a trickery (malandragem) composition as a positive façade. Romário had a distinctive history 
271 during the build-up of his heroism that fits within the mystifying process of Brazilian sporting heroes. In 1992, Romário did not accept to stay on the bench in a friendly football match against Germany. Because of this fact among other disciplinary misbehaviours, he was excluded from the Brazilian squad for the next two years. During qualification for the 1994 FIFA World Cup, Brazil would face Uruguay in its last match and needed to win in order to classify to that championship. The technical commission emphasised the discipline and tactical requirements for the players and Romário did not fit in these requirements, but he was already internationally recognized as a great football player and goal-scorer. His re-incorporation to the team happened for that last match and he scored the two goals that classified Brazil to the 1994 World Cup in a Maracanã stadium full of 100,000 spectators. His ability and performance as a goal-scorer redeemed his undisciplined record and his laziness during training practices. The cycle would be completed: from a discredited situation, the hero attended the call to save the team and successfully fulfil his role with talent and irreverence. His indiscipline turned him into a political rebel that criticised the Brazilian football establishment - he became a politicized malandro (Helal, 2003).

Later, Romário had a main role on the winning team for the fourth Brazilian title of FIFA World Cup after 24 years. A significant number of the current electorate followed Romário's career and admire his achievements through the Brazilian team. Moreover, many may also believe that Romário represents a 'true' Brazilian, someone who does not fit in every rule, but has talent and overcome social barriers to be successful, even if he needs to fight for changes in those rules. For some people, these characteristics are not desirable for a politician, but Romário managed to conquer a significant electorate from his personality.

The combination of football stardom and politicalised climate helps a celebrity like Romário to access politics. Understanding the electorate political behaviour that elected Romário requires an overview of the Brazilian politics. Voting is obligatory for all citizens between 18 and 70 years old and it is optional for people between $16-17$ years-old, as well as those who are over 70 years old. For the 2014 elections, the total electorate totalled 142.8 million voters (Tribunal Superior Eleitoral, 2014a). The system is open to many political parties currently the Superior Electoral Tribunal records 32 parties (Tribunal Superior Eleitoral, 2015). Therefore, alignment and suffrage are not necessarily sustained upon ideological approaches. Balbachevsky and Holzhacker (2004) suggest three main explanations for voting: as an expression of identity with the candidate; as a belief on a potential opposition that the candidate represents; or an expression of the belief on the candidate's management capacity. These positions reflect low levels of information and the uninformed political opinions of the majority Brazilian electorate. In this sense, the interests/parties' versus 'people's interest/parties', but also the perception on candidate's image of competence and honesty (Borba, 2005).

For these reasons, Romário's political achievements rely more on how the electorate perceive his personality and fame instead of his ideological and political approaches. His 
316 party, the Brazilian Socialist Party (PSB), claims in its manifesto to express the socialist 317 aspirations of Brazilians aiming to socialise the means and results of economic production 318 while recognizing "democratic and liberal conquers" of humanity. The party admits the 319 possibility of working within the capitalist system, but it believes that only the socialist 320 approach would be the final solution for the social issues (PSB, 2015). One year after his 321 election for national deputy, a rumour that Romário would leave PSB was quickly denied 322 by him on Twitter: "Reality is simple and clear: I'm socialist and I believe I will stay in PSB 323 until the end of my office period" (Romário, 2011). Although he and his party claims to be 324 socialists, we cannot extend that the ideology conquers Romário's votes, especially 325 because socialism is usually discredited as a political system in Brazil. Considering the 326 trends identified by Brazilian political science studies, it is very likely that the majority of 327 Romário's voters do not know his party affiliation or are informed about the PSB's 328 manifesto.

Romário's electoral share has increased since first coming to office, which suggests that he is not simply trading on his sporting capital. For the 2010 elections, in Rio de Janeiro approximately 9.5 million people voted and about 7.4 million voted for one specific candidate -0.5 million voted for a party instead of a candidate and 1.5 million nulled their vote or voted blank. Romário received 146,859 votes, being the sixth most voted deputy in Rio de Janeiro for that election, among 751 candidates (Tribunal Superior Eleitoral, 2010; Andrade, 2014). On that occasion, Romário received $30 \%$ of PSB's votes for national deputy in Rio de Janeiro (Tribunal Superior Eleitoral, 2010). For the 2014 elections, 7.3 million people voted on senator candidates and Romário received 4.68 million votes (63.4\%), being the most voted senator in the history for Rio de Janeiro state. His main contender, former Rio de Janeiro city mayor on three legislations Cesar Maia, received 1.5 million votes (20.5\%). Together with Romário, the PSB elected two other senators among the 27 states (Tribunal Superior Eleitoral, 2014b; Andrade, 2014).

During Romário's office period as national deputy (2011-2014), he was vice-president of the Tourism and sport commission of the Deputies Chamber in 2011 and then elected president in 2013, surrogate on the Commission for education and culture, vice-president on the Parliamentary front for people with disabilities and Director for sports and accessibility themes on the Parliamentary front for physical activity. In 2014, last year in office, PSB indicated Romário to join the Participative Legislation Commission as a surrogate, what may be seen as a strategy to expand the areas of action beyond sport to conquer visibility and legitimacy in future elections. These commissions are similar to working groups on specific topics that might be permanent or temporary, being the main space for legislation and inspection (Brasil, 2015).

Partly due his work in these commissions, Romário presented 17 information requirements, 79 general requirements and 7 indications. More significantly, he authored or co-authored 21 law projects on topics related to people with disabilities (7 projects), sport (5 projects), strategies against corruption (3 projects), education (3 projects) and strategies against sexual abuse and sexual harassment ( 3 projects). Nine of Romário's projects were appended to previous proposals, seven were archived for not corresponding 
361 to the Chamber's internal rules, four projects still wait for reviews and only one is expected 362 to be discussed by the plenary. These were also the main topics of his 48 discourses at 363 the plenary, but he frequently used his speeches to promote sports events and Brazilian 364 participation on them, to criticise sports governing bodies and to salute actions related to people with disabilities. Romário also required the establishment of an investigation on the Brazilian Football Confederation, which had enough signatures but it was not accepted by the Chambers presidency. During his legislature, 13 of his 48 discourses focused on criticism on the management of the Brazilian Football Confederation, another five mentioned his worries due to the preparation for the 2014 FIFA World Cup and one focused on corruption allegations against the Volleyball Brazilian Confederation. Mentions to people with disabilities and Down syndrome appeared in 14 of his discourses (Brasil, 2015).

These proposals are arguably appealing and significant for the public, bringing media attention and visibility to Romário and to his advocated causes. He appeared to be very active on presenting proposals and participating in commissions. However, during his years in office, he was not competent on legislating and implementing his proposed policies. Confirming the thesis on the disinformation of the Brazilian electorate, his senate election are supported on the successful capacity of image creation and the power of discursive strategies to attract voters, instead of an efficient legislation.

Understanding the audience is a key part of the celebrity (Rojek, 2001), Romário acknowledges and reinforces his link to his electorate. In a speech given in Parliament on $8^{\text {th }}$ October 2014, he declared:

It's not everyday that a former slum inhabitant is elected senator of the republic and it is not everyday that a candidate receives 4,683,963 votes. For this reason, I will leave the modesty aside to say that this is an historical moment for the parliament and for my state. I'm very honoured to become the most voted senator in the history of Rio de Janeiro. And this fact only increases my responsibility... Some say that I don't have enough experience and I'm acquiring it, but I'm sure I have some experience that those who were born with a silver spoon don't have. I refer to the experience of walking $6 \mathrm{~km}$ on foot to go to the school, the experience of almost starve in the childhood, of not having a fridge at home, of the difficulties of going to the training sessions when I was a teenager... I also refer to the experience of losing friends to criminality and drugs addiction. Maybe I was elected because a part of the population is tired of the same as always and want to see in the congress people with their face (Faria, 2014).

Through this speech, Romário highlights how he has attracted the most votes of any senator in the history of Rio de Janeiro. He argues that this was due to two factors. More broadly, it was due to dissatisfaction with the existing political class, particularly considering that his concurrent were a career politician. Specifically it was down to his appeal with the electorate. He did not refer to his sporting exploits, but referred to the fact that he was from the same social background as his electorate and understood their travails and concerns. As the Brazilian political science shows, the candidate personality 
constitutes the historical basis for structuring the electoral behaviour (Borba, 2005), and this is still the case to explain and how Romário explores his political persona.

The role of the audience is vital for the charismatic politician. Romário highlights that his audience came from the same social background where he grew up, but this is changing based on his performance as a politician:

\begin{abstract}
"On the streets, I notice that $80 \%$ of those who voted for me are from the lower social classes. Nowadays, many people from the richer social class greet me and say that would vote for me in the next elections. I win the credibility from those who thought I would be another fool that entered the politics to defend lost causes or to steal. Damn, there are deputies for 16 years who did not a single shit!" (Bastos, 2012)
\end{abstract}

His perceived credibility were conquered on law proposals that were not accepted. Now, as a senator, he repeats the same policy foci, proposing the same laws once denied in the Chambers through the Senate. His three policy strands are inextricably tied to his own background story, as well as resonating with the poor in Rio and more generally in Brazil. Part of this is to provide suitable healthcare to his constituents, but also using sport to promote healthy lifestyles. He has a daughter with Down's Syndrome, and this is another key element to his support for healthcare. Finally, he campaigns against corruption in the CBF and government. It is this area that is winning him support from other social groups.

Romário currently maintains two websites: one for Romário the footballer (http://romario11.com.br); and one for Romário Faria the politician (http://www.romario.org). The same applies to his Facebook pages, where the footballer has 0.5 million fans and the politician has 1.8 million fans. He is carefully presenting himself to his diverse audiences - football fans and the electorate. The website for Romário's election campaign for national deputy (www.romario4011.com.br) clearly illustrated his intention to draw on his football appeal, whilst at the same time not alienating his audience. Despite playing for three of Rio's four biggest clubs (Vasco da Gama, Flamengo and Fluminense), Romário chose not to display these club affiliations on his political promotions. Instead, he is seen sporting the green and gold jersey that symbolises Brazilian football. His dedication to his home city of Rio is reinforced on his parliamentary website (http://www.romario.org). The headline banner utilises prominent architectural symbols from Rio's skyline, including the statue of Christ the Redeemer. It also utilises another famous Rio landmark, the Maracanã stadium. This is more detailed than the other landmarks and sits prominently at the centre of the banner. Football and the city are also reinforced through the design of Romário's name; on the website it is spelled RomáRio to emphasise the city. The final 'o' is shaped like a 'speech bubble' that suggests that the senator is someone who will say what needs to be said. The link to his former career is emphasised with a 'full-stop' in the shape of a football.

His political website brings together the various proposals he championed as a national deputy and currently as a senator. The website summarises the proposals on eleven topics: harassment in public transportation; Olympic and Paralympic fund; constitution at 
453 schools; corruption; revenge pornography; scientific research; people with disabilities; 454 school inclusion; funding to para-sports; sexual abuse; and sport in schools. It reinforces 455 that his policy priorities are related to sport, disabilities, social justice, and corruption. The 456 current status of these projects is not clarified, so it demonstrates that he is very active as 457 a senator. Whilst all these topics are unarguably significant, the majority were appended or 458 archived at the deputy chambers and then again brought in the senate, as mentioned 459 previously. As he did as a player, he built on the work of others, rather than creating 460 everything himself.

Romário makes use of a variety of 'media spectacles' (Kellner 2010) to present his approach. He takes opportunities to present himself as a man of the people, as well as making political points. Romário the politician spoke about the London 2012 Olympics and Paralympics on $6^{\text {th }}$ September 2012. In what Rojek (2001) would call 'staged celebrity', the timing of Romário's speech coincided with a national holiday. September $7^{\text {th }}$ is Independence Day in Brazil and many Brazilians take extended holidays. Romário delivered his speech to an empty parliament as many of the politicians had already left for their vacation. The simple act of delivering the speech to an empty chamber reiterated that Romário was a full-time politician and worthy of public support. It also reinforced the impression that other politicians were not full-time professionals. His political website not only presented his speech as a news story and provided a transcription, but it also published a photograph of his occasion. Many photographs of politicians are taken from the front, with the photographer (and therefore the audience) looking up the politician. This gives the speaker an air of grandeur and importance as well as demonstrating their leadership qualities. For this speech, however, the photograph is taken from over Romário's left shoulder. The footballer-politician is illustrated from the left side, his face barely visible. The key message from the photo is not the gravitas of the speaker but the reaction of the audience, or lack of them. The deputies had already left for their holiday and Romário was making this point clear.

\section{Football as a metaphor for politics}

Romário is using football, and to a lesser extent the Olympics, as a metaphor for government. In doing so, he is speaking the language of his electorate, and widening his appeal. The metaphor of football is a useful skill to communicate with the electorate. Mascarenhas et al (2014) argue that a significant feature of Lulism, the popularity of the former President Lula, was his ability to speak the language of football. Lula would equate politics with football and insert footballing terms into his speeches. He would refer to teamwork and the quest for victory. He equated his political successes and defeats with the fluctuation of his football team Corinthians. By using the language of football to describe political points, he communicates clearly to a significant proportion of the electorate (Goldblatt, 2014). This form of 'football-politics' (Porro and Russo, 2000) helps to simplify political language. In doing so, it promotes the politician as a 'man-of-thepeople' and appeals to their electorate (Mascarenhas et al, 2014). Romário is replicating this approach. Not only does it reflect his previous career, it also reinforces that he is a 'man-of-the-people'. His celebrity profile helps to amplify his message as it has given him a 
public platform. An outspoken critic like Romário, will fill valuable airtime on television, and provide additional debate. Significantly, it also maintains Romário's position in the media and highlights that he is talking the same language as the electorate.

Romário frequently refers to the corruption of the football federation and the impact that this has had on the national team and club football. His focus on the corruption of the CBF, FIFA, and World Cup led him to contribute a foreword to Andrew Jenning's (2014) book on FIFA and corruption. Jennings is an investigate journalist who has spent a number of years exposing bribery and dubious governance at football's world governing body. Romário thanked Jennings for providing him with the material to challenge and requests more so he can keep up the fight. More importantly, he highlights how poor governance is directly impacting events on the pitch. The day after Brazil were humiliated by a 7-1 defeat to Germany in the semi-final of the 2014 World Cup, Romário provided his analysis:

\begin{abstract}
Yesterday was a very sad day for our football. Those with good memories will remember my words: "Off the field, we have already lost the World Cup". Sadly it was no different on the field. There is a crisis in our beloved sport. You think the problem is only the players or (coach Luiz Felipe) Scolari? No way. Our football has been deteriorating for years, being sucked dry by talentless moguls. [President] Dilma will have to present the cup to another team. They will take the cup and we will be left with our overpriced stadiums and no material legacy. This is the cup of shame (Ashton, 2014).
\end{abstract}

Rather than blame the players and coach, he identified the problems off the pitch as being the issue. Moreover, he focused on the costs of hosting the World Cup and how this shames the nation, rather than the defeat itself.

More importantly, Romário uses football as a metaphor for wider society. He draws analogies between the focus on political elites on mega-events, rather than on providing quality services for the poor. In an interview with the BBC, he was asked by the journalist Stephen Sackur whether calling FIFA executives thieves, blackmailers and a cancer was the right sort of language to be using when Brazil was being placed under the spotlight across the world. Romário responded:

I don't know if this is the language used here in Brazil by Brazilians, but this is how I speak. This is how I see these people, people who are really harming Brazil, and Brazilian sport, specifically Brazilian football. These are people who, in my opinion, have no credibility whatsoever. But unfortunately there is an elite in Brazilian politics that let these people do what they are doing. In my opinion they are causing great damage to our country's image... There's here this idea that everything for the World Cup should be up to the FIFA standard and people have been told that the FIFA standard is $100 \%$ quality. Why can't we have the FIFA standard, the quality, in hospitals, schools, public transport, security, disabled access? These are what people are demanding in the streets. And the people are right, I agree with them (BBC, 2014).

He questioned the existing political elites that permits corruption and fraud, not only in football but across society. More importantly, he uses the language of football to call for 
546 better quality in public services. The link is that corrupt official demand certain quality standards when demanding commercial advantages, but they cannot do the same for the general public. Those in power demanded certain advantages for their own financial gain, rather than for the public benefit.

\section{Conclusion}

Sporting celebrity politicians attain their exalted position thanks to a number of factors. Through their sporting prowess they attain positions of national and international standing. The media and cultural industries help promote the sporting hero as a celebrity, which sustains their image in the public sphere, and can bring financial rewards. In the politicised world of Brazilian football, footballers assumed a political position. Star players like Sócrates advocated for democracy and were publically political. With the growth of celebrity footballers, openly political views have receded. Gilchrist (2005) has argued that in the globalised commercial world of contemporary sport, these sporting celebrities tend to be apolitical so as to maintain their commercial contracts.

Romário had a few political insights as a player, yet this became more visible after he retired. He is a global football star who has traded on this public recognition to enter politics. This makes him a 'famed non politico' (West and Orman, 2002) or a 'celebrity politician' (Street, 2004, 2012; Marsh et al, 2010). Now Romário is establishing a separate career as a politician, his political stance is emerging. Celebrity politicians operate in similar ways to sporting heroes.

Being a footballing celebrity clearly provides a significant profile for someone entering politics. This is more advantageous in Brazil where much of the nation's historic national identity has been projected through football. Undoubtedly, Romário has utilised this appeal to his political advantage. His presentation of self during his campaign and on his political webpage clearly draw on his football background. Romário communicates with his electorate using the tools of his football stardom. He uses the full range of social media, a website, twitter, Facebook, and a blog, in order to communicate directly with the voters. In this way, he avoids the monopoly of Globo who may moderate or amend his message. This allows him to present himself as the anti-politician; a 'man-of-the-people' who reflects the average voter in his constituency. Street (1997) highlights the importance of soundbites as they are easy to broadcast on television. Romário's use of twitter and Facebook help him deliver short comments to the electorate. They are soundbites for the Internet generation. More importantly, it also makes him appear accessible and the focus of his polices reflects this.

Furthermore, he utilises the language of football, as Lula did before, to speak in a way that the voters understand. Romário uses football as a metaphor for wider society. Not only does he identify the corruption and fraud that is taking place in the CBF, he draws the analogy that this money could be better spent on public services to help the poor. In this way he is resonating with his audience and maintaining his public profile. This is also setting himself apart from the traditional political class who are also seen as corrupt, 
591 ineffective and apathetic about poor's problems. By utilising the cultural capital of their 592 previous career and the idea of overcoming the poverty to become an international well593 succeed football player, whilst simultaneously campaigning on key issues, a sporting 594 celebrity politician like Romário can win popular support and maintain their public profile.

\section{Acknowledgements}

The authors would like to extend their gratitude to the anonymous reviewers who's constructive and useful comments have greatly improved this article.

\section{Endnotes}

'Romário is also known by his nickname of Baixinho ('Shorty')

ii Throughout a similar period, Portugal was a dictatorship under Salazar, as was Spain under Franco. To a lesser extent, Mussolini's Italy and the 'Regime of the Colonels' in Greece also highlight similar dictatorships.

\section{References}

Abercrombie N and Longhurst B (1998) Audiences: A Sociological Theory of Performance and Imagination. London: Sage.

Almeida BS, Marchi Júnior W, and Pike E (2014) The 2016 Olympic and Paralympic Games and Brazil's soft power, Contemporary Social Sciences 9(2): 271-283.

Anderson B (2006) Imagined communities: reflections on the origin and spread of nationalism. London and New York: Verso.

Andrade, H (2014) Romário (PSB) supera veterano Cesar Maia (DEM) e é eleito senador pelo Rio. UOL Notícias, 05 Oct. 2014. Available at

http://eleicoes.uol.com.br/2014/noticias/2014/10/05/romario-supera-veterano-cesar-maiae-e-eleito-senador-pelo-rio.htm, accessed on 16 May 2015.

Andrews DL and Jackson SJ (2001) Sport Stars: The Cultural Politics of Sporting Celebrity. London: Routledge.

Archetti EP (2001) The spectacle of a heroic life: the case of Diego Maradona. In: Andrews DL and Jackson SJ (eds) Sport Stars: The Cultural Politics of Sporting Celebrity. London: Routledge, pp. 151-163.

Ashton N (2014) Romario slams 'talentless moguls' for ruining Brazilian football after humiliating 7-1 semi-final defeat to Germany. Daily Mail, 9 July, 2014. Available at: http://www.dailymail.co.uk/sport/worldcup2014/article-2686602/Romario-slams-talentlessmoguls-ruining-Brazilian-football.html (accessed 11 Dec 2014).

Axford B and Huggins R (1998) Anti-politics or the triumph of postmodern populism in promotional cultures? Telematics and Informatics 5(3):181-202.

Balbachevsky E \& Holzhacker DO (2004) Identidade, oposição e pragmatismo: o conteúdo estratégico da decisão eleitoral em 13 anos de eleições. Opinião Pública, 10(2): 242-253.

Bang HP (2004) Cultural governance: governing reflexive modernity. Public Administration 82(1):159-190.

Baquero, M (2000) A vulnerabilidade dos partidos políticos e a crise da democracia na América Latina. Porto Alegre: Ed. Universidade/UFRGS, 2000.

Bastos C (2012) Peixe Vivo. Rolling Stone, 67, April 2012. Available at: http://rollingstone.uol.com.br/edicao/edicao-67/peixe-vivo\#imagem0 (accessed 11 December 2014). 
\begin{tabular}{llccccc}
\hline BBC $\quad(2014)$ & HardTalk, & 8 & April & 2014. & Available & at: \\
http://www.bbc.co.uk/programmes/n3csw9f0 & (accessed & 11 & December 2014). & &
\end{tabular}

Boorstin D (1971) The Image: A Guide to Pseudo-Events in America. New York: Atheneum.

Borba J (2005) Cultura política, ideologia e comportamento eleitoral: alguns apontamentos teóricos sobre o caso brasileiro. Opinião Pública, 11(1): 147-168.

Brasil (2015) Câmara dos Deputados. Available at http://www2.camara.leg.br, accessed on 16 May 2015.

Corner J (2000) Mediated persona and political culture: dimensions of structure and process. European Journal of Cultural Studies, 3(3): 389-405.

Corrigan P (2001) Imran Khan: The road from cricket to politics. In: Andrews DL and Jackson SJ (eds) Sport Stars: The Cultural Politics of Sporting Celebrity. London: Routledge, pp. 231-242.

Drumond, M. (2009) O esporte como política de estado: Vargas. In: Del Priore M and Melo VA (eds) História do Esporte no Brasil. São Paulo: Editora UNESP, pp. 213-244.

Durkheim E (1915) The Elementary Forms of the Religious Life. London: Unwin.

Eco, U (1990) A guide to the Neo-Television of the 1980s. In: Baranski, Z. and Lumley, R.

(Eds.) Culture and conflict in postwar Italy: essays on mass and popular culture. New York:

St. Martin Press.

Faria R (2014) Discurso de agradecimento pela eleição para o Senado Federal. 8 October 2014. Available at: https://www.youtube.com/watch?v=8cRbUcR7RPs (accessed 11 December 2014).

Folha de S. Paulo (2014) Confira lista de ex-jogadores de futebol eleitos nestas eleições. São Paulo, 08 Oct. 2014. Available at http://www1.folha.uol.com.br/poder/2014/10/1529143-confira-a-lista-de-ex-jogadores-defutebol-eleitos-nestas-eleicoes.shtml, accessed on 16 May 2015.

Fraga P (2014) Romário fala muito. Revista Trip, 26 November 2014. Available at: http://revistatrip.uol.com.br/revista/238/paginas-negras/romario-fala-muito.html (accessed 11 December 2014).

Gamson, J. (1994) Claims to Fame: Celebrity in Contemporary America. Berkeley: University of California Press.

Gilchrist P (2005) Local heroes and global stars. In: Allison L (ed) Global politics of sport. London: Routledge.

Giulianotti, R (1999) Football: a sociology of the global game. Cambridge: Polity Press. (1999)

Goldblatt, D (2014) Futebol Nation: A Footballing History of Brazil. London: Penguin. Hall S (1980) Encoding/Decoding. In: Hall S, Hobson D, Lowe A, and Willis P (eds) Culture, Media, Language: Working Papers in Cultural Studies, 1972-79. London: Hutchinson, pp. 128-138.

Helal R (2003) Idolatria e malandragem: a cultura brasileira na biografia de Romário. Revista Brasileira de Ciências da Comunicação, 26(2): 24-39.

Holanda SB (1995) Raízes do Brasil, 26. ed. São Paulo: Companhia das Letras.

Jennings A (2014) Omertà: Sepp Blatter's FIFA Organised Crime Family. London: Transparency Books.

Keane J (2002) Whatever Happened to Democracy? London: IPPR.

Keane J (2009) The Life and Death of Democracy. New York: Simone \& Schuster.

Kellner D (2009) Barack Obama and celebrity spectacle. International Journal of Communication, 3(1):1-20. 
Kellner D (2010) Celebrity diplomacy, spectacle and Barack Obama. Celebrity Studies 1(1): 121-123.

Leite Lopes JS (2007) Transformations in national identity through football in Brazil: lessons from two historical defeats. In: Miller RM and Crolley L (eds) Football in the Americas: Fútbol, Futebol, Soccer. London: Institute for the Study of the Americas.

Lever J (1983) Soccer Madness: Brazil's Passion for the World's Most Popular Sport, Chicago: University of Chicago Press.

Lipow A and Seyd P (1996) The Politics of Anti-Partyism. Parliamentary Affairs 49(2): 273284.

Maguire, J (1999) Global Sport: identities, societies, civilizations. Cambridge: Polity Press. Marsh D, t' Hart P and Tindall K (2010) Celebrity politics: the politics of the late modernity? Political Studies Review 8(3): 322-340.

Marshall PD (1997) Celebrity and Power: Fame in Contemporary Culture. Minneapolis: University of Minnesota.

Mascarenhas F, Silva SR and Santos MR (2014) Lulismo e futebol: os discursos de um torcedor presidente. Movimento 20(2): 495-517.

Meštrović SG (1997) The Postemotional Society. London: Sage.

Meyer T (2002) Media Democracy: How the Media Colonize Politics, Cambridge: Polity Press.

Negreiros PL (2009) O Brasil no cenário internacional: Jogos Olímpicos e Copas do Mundo, in: Del Priore M, and Melo VA (eds) História do Esporte no Brasil. São Paulo: Editora UNESP, 293-330.

Pitt-Brooke J (2013) Joao Havelange guilty of taking bribes for World Cup rights but 'clumsy' Fifa president Sepp Blatter escapes. The Independent, 1 May 2013. Available at: http://www.independent.co.uk/sport/football/news-and-comment/joao-havelange-guilty-oftaking-bribes-for-world-cup-rights-but-clumsy-fifa-president-sepp-blatter-escapes8598250.html (accessed 15 January 2015)

Porro N and Russo P (2000) Sport and society in Italy today - Berlusconi and other matters: The era of 'football-politics' Journal of Modern Italian Studies 5(3) pp348-370.

Postman N (1987) Amusing Ourselves to Death: Public Discourse in the Age of Show Business. London: Methuen.

PSB (2015) Manifesto. Available at http://www.psb40.org.br/fixa.asp?det=1, accessed on 16 May 2015.

Putnam RD (2000) Bowling Alone, New York: Simon \& Schuster.

Ramet SP (1994) Rocking the State. Boulder, Co: Westview.

Rojek C (2001) Celebrity. London: Reaktion Books.

Sennett R (1976) The Fall of Public Man. Cambridge: Cambridge University Press.

Smart B (2005) The Sport Star. London: Sage.

Smith AD (1987) The Ethnic Origins of Nations. Oxford: Wiley-Blackwell.

Souza J (2014) O 'esporte das multidões' no Brasil: entre o contexto de ação futebolístico e a negociação mimética dos conflitos sociais. PhD Thesis, Universidade Federal do Paraná, Brazil.

Street J (1997) Politics and popular culture Cambridge: Polity Press.

Street J (2004) The celebrity politicians: political style and political representation. British Journal of Politics and International Relations 6(4): 435-452.

Street J (2012) Do celebrity politics and celebrity politicians matter? British Journal of Politics and International Relations 14(3): 346-356.

Swanson D and Mancini P (eds) (1996) Politics, Media, and Modern Democracy. New York: Praeger. 
Szemore A (2001) Up from the Underground: The Culture of Rock Music in Postsocialist Hungary. Pennsylvania: The Pennsylvania State University Press.

Tribunal Superior Eleitoral (2010) Eleições 2010 - Estatísticas e resultados da eleição. Available at http://www.tse.jus.br/eleicoes/eleicoes-anteriores/eleicoes-2010/estatisticas, accessed on 16 May 2015.

Tribunal Superior Eleitoral (2014a) Faltam 26 dias: voto é obrigatório para brasileiros de 18 a 70 anos. Notícias TSE, 9 sept. 2014. Available at http://www.tse.jus.br/noticiastse/2014/Setembro/faltam-26-dias-voto-e-obrigatorio-para-brasileiros-de-18-a-70-anos, accessed on 16 May 2015

Tribunal Superior Eleitoral (2014b) Eleições 2014 - Estatísticas e resultados da eleição. Available at http://www.tse.jus.br/eleicoes/estatisticas/estatisticas-eleitorais-2014resultado, accessed on 16 May 2015.

Tribunal Superior Eleitoral (2015) Partidos políticos registrados no TSE. 27 jan. 2015. Available at http://www.tse.jus.br/partidos/partidos-politicos/registrados-no-tse, accessed on 16 May 2015.

Turner G (2004) Understanding Celebrity. London: Sage Weber M (1948) From Max Weber: Essays in Sociology. London: Routledge. Weber M (1968) Economy and Society. New York: Bedminster Press. West D and Orman J (2003) Celebrity Politics. Englewood Cliffs: Prentice Hall. Whannel G (2002) Media Sport Stars: Masculinites and Moralities. London: Routledge. Wicke P (1992) "The times they are a-changin": rock music and political change in Eastern Germany. In: Garolfalo R (ed) Rockin' the Boat: Mass Music and Mass Movements. Boston, Ma: South End Press, pp. 81-93. 